sues in academic library costs and funding, with special attention to the effects of new technology and cooperation on both management and costs. It also presents the results of some studies of costs of operating research libraries and of formal library cooperation programs sponsored by CLR in recent years. The "Summary and Conclusions" chapter is a recap of seminar highlights. The book also contains three substantive appendixes: one by Michael Cooper on "Economic Issues and Trends in Economic Libraries"; one by Mark Cain, reporting on four case studies of university library management and rapid technological change; and an annotated bibliography on user fees and library economics by Jane Rosenberg.

The value of a good literature review is twofold: first, in the way that it organizes the literature and links publications it gives the reader a map of its subject, organizing the questions and concerns of the field by way of the relationships among publications. Second, it digests the literature, indicating which is the most important, pointing the reader toward literature relevant to his or her concerns and reporting the highlights of works that the reader may never see. This book does review a large body of important literature that has not been brought together before. However, it does not succeed very well at either of a literature review's missions.

Its structure is confusing. User fees, for example, are discussed in at least three different places. The succession of subjects often seems arbitrary. The overall effect is fragmentation: the reader gets useful snippets of information, but loses the overall structure. (The appendix by Cooper is an example of how the book could have been structured more effectively.)

As a digest of the literature, the comprehensiveness of the coverage of certain subjects is questionable. For example, the discussion headed "Cost Accounting in Libraries" refers almost exclusively to attempts to determine the costs of library automation-not the same subject. Some of Kantor's important work on academic library costs and economies of scale is cited, but some of his other equally relevant work is missed.
The book suffers some from occasional misstatements and lack of clarity: it seems to need a knowledgeable editor. For example, a lengthy discussion of "unit costs" never specifies whether that means average or marginal costs. "Cost benefits" is used repeatedly as a noun, a novel construction. The cryptic summary of D'Elia and Walsh's path-breaking research on user evaluation of libraries and library services is inadequate for the reader unfamiliar with the original. And the author periodically interjects editorial comments with which his readers will take issue: for example, he misquotes Herb White as saying that in libraries, cost-benefit determination is meaningless and cost accounting pointless, then concludes that "this attitude suggests that librarians are irresponsible managers and consequently cannot be trusted to handle large budgets." The non sequitur is not White's. (This reference was wrong, too.)

The book does, however, cover a large body of literature, and, commendably, is not limited exclusively to research libraries. It is a useful if flawed introduction to some of the major problems and research findings on the costs of research libraries. And the author makes some provocative conjectures about the effect of changing technology on the academic library. This is an area where everyone wishes for a crystal ball; Cummings doesn't have one, but he does raise some interesting possibilities.-Nancy Van House, School of Library and Information Studies, University of California, Berkeley.

Marketing Instructional Services: Applying Private Sector Techniques to Plan and Promote Bibliographic Instruction. Papers presented at the Thirteenth Library Instruction Conference held at Eastern Michigan University, May 3\&4, 1984. Ed. by Carolyn A. Kirkendall. Ann Arbor, Mich.: Published for the Center of Educational Resources, Eastern Michigan Univ., by Pierian, 1986. 157p. $\$ 19.50$ (ISBN 0-78650-201-X) LC 86-60025.

As library instruction moved into the eighties, its advocates and implementors found that they had learned a great deal from the disciplines of education, psy- 


\section{ACQUISITION PERSPECTIVES}

6. Book House is in its fourth generation of automation. Our custom software allows us the flexibility to accept orders generated through your computerized system or in the mail. Our policy is to develop a working compatibility with the automated system in your library to facilitate receiving orders, transmitting open order reports and invoices electronically.

Let's explore interfacing your automation with ours.

\section{COMPLWE DHTWRY}

\section{MIRARY - Vत्XNDOR}

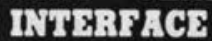

BOOK HOUSE
6
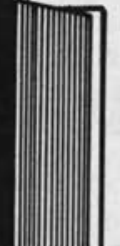

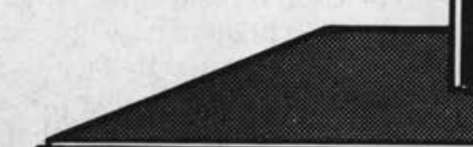

AUTOMFTHON

3 OPHN ORDHR RHPORTS ACCURATH BOOK

4

\section{Dसhपमत?}

CALL TOLL-FREE TODAY

1-800-248-1146

In Canada \& Michigan

CALL COLLECT (517) 849-2117

OCLC Vendor No. 17397

SAN 169-3859

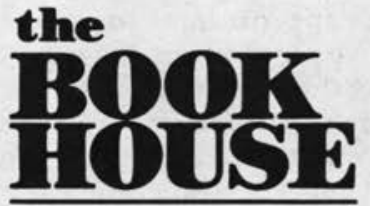

JOBBERS SERVING UBRARIES WITH ANY BOOK IN PRINT SINCE 1962

208 WEST CHICAGO STREET

JONESVILLE, MICHIGAN 49250 
chology, and information science. It was only natural that instruction librarians then began to look beyond the classroom walls at the broader arena in which they operated, and to investigate disciplines such as sociology and public relations. The LOEX conferences, sponsored under the leadership of Carolyn Kirkendall, are traditionally on the cutting edge of innovation. The proceedings of the thirteenth Library Instruction Conference, of which this volume is a compilation, are no exception-they pave the way for the integration of marketing concepts into the practice of library instruction.

As with any good professional conference, program offerings ranged from the sublimely theoretical to the prescriptively practical-a little consciousness raising and a little exemplification. And as any good opening paper would, Elizabeth Wood's comments span this spectrum. She discusses why instruction librarians should market their services and what self-serving obstacles they must overcome to do so effectively. She then goes on to provide a capsule summary of marketing theory and practice, complete with definitions, underlying principles, and steps to follow. In spite of a slight excess of jargon and transparencies, her instructions on how to implement a marketing program are informative and useful.

The underlying themes of the conference should have struck a familiar chord for the instruction librarians in attendance. One does not need formal training in marketing to recognize the tenets of model marketing performance, for they closely parallel the principles of good teaching. The emphasis of both services is on the consumer. Both marketing and instructional theory advocate that one analyze the needs of one's clientele, plan programs appropriate to those needs, prioritize programs, package products in a manner that is appealing and memorable, and promote products with enthusiasm and conviction. Paula Warnken's paper about her experience in adapting the Earlham model at Xavier draws heavily on the work of marketing theorist Phillip Kotler and clearly demonstrates the similarities between these disciplines. Many of
Peggy Barber's remarks in "Ten Things I Have Learned about Public Relations" could also easily have been about teaching.

Several papers in the collection indicate that the issues associated with marketing service organizations are just one step removed from the issues confronting instruction librarians in defining their roles in general. Warnken, for example, discusses the decade-old question of whether library instruction should be targeted to those with the greatest need, to those who are easiest to reach, or to the nonusers. Ian Malley's reflections on the lack of library instruction marketing in the United Kingdom subtly enumerate the environmental, cultural, and political circumstances needed to support and encourage widescale library instruction efforts. Virginia Tiefel's and Goodwin Berquist's companion pieces about the library instruction program at Ohio State University demonstrate a case in point of how librarians can, over time, be accepted by faculty as partners in the teaching-learning process and how marketing can facilitate that transition. As the reviewers read through the volume, we found ourselves asking "Are we marketing library instruction or are we marketing ourselves?"

In her introduction to the volume, the editor explains that the scope of the conference was limited in several ways. The lack of attention to needs assessment and evaluation is justified by the amount of literature already available on those topics. On the other hand, the nearly exclusive focus on the marketing of course-related instruction to faculty seems less than helpful to the novice marketer. So much of a library instruction program's success is determined by how it is perceived by administrators, how it is received by students, and how it is implemented by librarians. More mention should have been made of methods of guaranteeing success with these consumers and providers as well. However, the inclusion of seven poster session abstracts helped to fill this gap, as they highlight specific attempts to employ marketing techniques in specific library instruction programs. The bibliography on marketing library and informa- 
tion services by Kirkendall, Hannelore Rader's 1983 annotated bibliography on library orientation and instruction, and reproductions of handouts also add significantly to the value of the book.

William Miller's paper features prominently among the conference offerings. Speculating upon the consequences of overzealous advertisement on already deteriorating library collections and already overworked library staffs, he alludes to the need for skeptical investigation and strategic planning before advertising such a labor-intensive service. While one can debate the appropriateness of marketing library instruction, it is important to keep in mind a distinction between marketing a package and marketing a quality product. It is doubtful that any of the speakers would endorse a full-scale adoption of private sector marketing to library instruction. Rather, the conference proceedings do an excellent job of introducing the concepts, outlining appropriate steps in implementing marketings, cautioning against potential pitfalls, and providing examples of library-specific applications. As library instruction seeks to enhance its visibility in the eighties, this volume will serve as a stepping stone and a guidepost along the way.-Tara Lynn Fulton, Northwestern University Library, Evanston, Illinois.

\section{OTHER PUBLICATIONS}

1982 Census of Manufacturers: Concentration Ratios in Manufacturing. Washington, D.C.: U.S. Dept. of Commerce, Bureau of the Census, 1986. 180p. paper, \$13. LC 83-600153.

Affiliates \& Offices of Japanese Firms in USA \& Canada: 1986 Edition. Tokyo: JETRO (dist. by Gale), 1986. 559p. paper, $\$ 80$ (ISBN 4-82240326-2).

Afro-American Writers Before the Harlem Renaissance. Ed. by Trudier Harris. Detroit: Gale, 1986. 369p. \$88 (ISBN 0-8103-1728-1). LC 8612121.

ALA Survey of Librarian Salaries, 1986. Ed. by Mary Jo Lynch and Margaret Myers. Chicago: American Library Assn., 1986. 90p. paper, $\$ 40$ (ISBN 0-8389-3335-5).

The ALA Yearbook of Library and Information Services: A Review of Library Events 1985: Vol. 11 (1986). Ed. by Roger Parent. Chicago: American Library Assn., 1986. 419p. $\$ 70$ (ISBN 08389-0458-0).

American Poets. Ed. by Ronald Baughman. Contemporary Authors Bibliographical Series, no.2. Detroit: Gale, 1986. 387p. \$48 (ISBN 08103-2226-9).

American Publishers. V.1: U.S. Publishers A-M. V.2: U.S. Publishers $\mathrm{N}-\mathrm{Z}$ and ISBN Index. V.3: Canadian Publishers and ISBN Index. Ed. by Barbara Verrel. New York: Saur, 1986. 1,712p. paper, $\$ 40$ (ISBN 0-89664-375).

The Annual Register: A Record of World Events, 1985. 227th ed. Ed. by H. V. Hodson. Detroit: Gale, 1986. 562p. \$95 (ISBN 0-8103-2043-6). LC 4-17979.

Artist's Market: Where and How to Sell Your
Graphic Art, 1987. Ed. by Susan Conner. Cincinnati, Ohio: Writer's Digest Bks., 1986. 569p. (ISBN 0-89879-246-0).

Artist Biographies Master Index. 1st ed. Ed. by Barbara McNeil. Gale Biographical Index, no.9. Detroit: Gale, 1986. 700p. $\$ 85$ (ISBN 08103-2107-6). LC 86-14955.

Awards, Honors, and Prizes: An International Directory of Awards and Their Donors. V.2: International and Foreign. 6th ed. Ed. by Gita Siegman. Detroit: Gale, 1986. 576p. \$170 (ISBN 0-8103-0446-5). LC 85-07062.

Berdie, Douglas R.; Anderson, John F.; and Niebuhr, Marsha A. Questionnaires: Design and Use. $2 \mathrm{~d}$ ed. Metuchen, N.J.: Scarecrow, 1986. 344p. \$22.50 (ISBN 0-8108-1884-1). LC 86-1783.

Berger, Melvin. Hazardous Substances: A Reference. Hillsdale, N.J.: Enslow, 1986. 128p. $\$ 12.95$ (ISBN 0-89490-116-8). LC 86-8806.

Best Reference Books: 1981-1985. Ed. by Bohdan S. Wynar. Littleton, Colo.: Libraries Unlimited, 1986. 504p. \$45 (ISBN 0-87287-554-7). LC 86-15316.

Book Review Index: Reference Books, 1965-1984. Ed. by Barbara Beach. Detroit: Gale, 1986. 700p. $\$ 125$ (ISBN 0-8103-2195-5).

Business Organizations, Agencies, and Publications Directory. Ed. by Kay Gill and Donald P. Boyden. Detroit: Gale, 1986. 2v. 2,031p. set, \$265 (ISBN 0-8103-2097-5).

Caster, Lillie D. The Classifier's Guide to LC Class $H$. New York: Neal-Schuman, 1986. 143p. paper, \$29.95 (ISBN 0-918212-99-5). LC 8528459. 